田村鋒男・小林良昭

$\mathrm{X}$ 線フィルムのデジタル化にあたり，光にるイメージ ングプレートのイレース（消去）操作を利用して胸部 X 線フィルムとあらかじめ X 線を均等曝射させて励起状 態にさせたイメージングプレートとの密着露光を行い FCR 装置による通常処理を行ってデジタル化を試みた。 結果原画像に比して光学的ボケによる鮮鋭度の低下をき たした。さらに露光時間の短縮を求めた結果粒状性が低 下したが診断上良好な FCR 画像を得ることができた。 と同時にフィルムの記録，保管も可能となった。また再 撮影することなく画像処理を行うことによって任意の画 像を得ることが可能となった。

\section{SN 比スペクトルによる至適写真濃度の検討}

滋賀医大病院放射線部

○小水 満・大西英雄・本田秀人 大阪大学医療技術短大 曾我部秀一

〔目的〕日常行われているX X 線撮影では, 被写体厚さ の変化や目的部位，また使用する secreen-film システム によって，常にバラツキが生じ至適写真濃度が変化する。 すなわち，目的とする信号の検出能が写真濃度により影 響を受ける。そこで，至適写真濃度を得るために，信号 のスペクトルとノイズスペクトルとから空間周波数ごと の $\mathrm{SN}$ 比 (SN 比スペクトル)を求め，これが最大となる 写真濃度について検討したので報告する。

〔結果〕 SN 比スペクトルの手法を使って，各信号に 対する空間周波数ごとの至適写真濃度が定量的に求めら れた。

\section{4. 胸部単純撮影における縦隔部描出能の検討（フィル ム中心に)}

大阪府立羽曳野病院放射線科

○谷口義則・藤岡富雄・山口道弘 長瀬産業株式会社コダック製品事業部 嵯峨山英樹

〔目的〕胸部正面写真に抢いて縦隔部の描出は重要で ある。今回われわれは，高圧（補償フィルタ，ノンフィ ルタ）で 4 種のフィルムの描出能，物理特性を検討した。 〔方法〕 4 種のフィルム (TMG， OG，TMC，OC)の MTF, RMS 粒状度, HD 曲線, ROC を求めた。線質 140 $\mathrm{KVP}$ 補償フィルタおよびノンフィルタで胸部ファント ム (KODAK 社 CTO) を用い縃隔描出能の検討および臨 床的評価をした。

〔結果〕縦隔部の描出能は補償】ィル夕使用時に TMG, OG, TMC, OCでノンフィル夕時, TMC, OC, TMG, OG の順に良功た。臨床評価は補償フィル 夕使用時が高かった。
〔結論〕䋛隔の描出能は補償つィル夕を用い HD 曲 線の直線部に入れた TMG が良く，臨床的評価もよい。 が，操作性等を考慮すれば TMC も縦隔の描出に有効で ある。

25. シネ X 線写真のコントラストの理論的考察 東海大学医学部付属病院放射線診断科

○原口信次・田中啓子・瀨尾 誠 長山鎑治郎・湯之上未已

造影剤を用いた X 線像のコントラストを考えるとき， 最も重要なことは，造影剤と人体組織の吸収差である。

よって，今回，われわれは，ヨード系造影剂を用いた。 シネ X 線写真の被写体コントラストが, ヨードと人体組 織の吸収差に依存することに着目し，X線エネルギー と，吸収係数の関係を求めるとともに，散乱線の影響を 含めたものを，被写体コントラストと考元，さらに，現 像条件とフィルムコントラストの関係を求めることによ り，被写体およびフィルムコントラストの積が一定とな るような撮影，現像の至適条件を求めるための，理論的 考察を行った。 な扔, 臨床に扔いては, 十分満足の行く 結果が得られた。

26. センシトメトリーによる自動現像機の自動管理 昭和大学病院放射線部 ○中澤靖夫・成谷竹信 新田 勝・神田幸助

〔目的〕自動現像機の管理はディリーチェック，ウェ クリーチェック，マンスリーチェックという方法でトー タルにとりくさ必要がある。私達はセンシトメトリーの 情報をマイクロコンピュータに入力し，管理限界，H-D 曲線，特性曲線因子を自動的に算出し管理する方法を考 案したので報告する。

〔結果〕管理限界と管理 STEP 濃度との関係を知る ことができる．H-D 曲線，特性曲線因子の算出が自動的 に行うことができるので, 自動現像機の動的特性の把握 が可能となった。用いた数式モデルは

$$
D=\frac{D m-D f}{H(S \cdot E)^{-\mathrm{c}}}+D f
$$

文献 1) 日写誌, 39(3)，123-130，(1976).

\section{7. $\mathrm{X}$ 線管固有滤過と $\mathrm{X}$ 線スペクトルとの関係}

名古屋大学医療技術短期大学部 診療放射線技術学科

○橋本幹男・前越 久 津坂昌利・田宮 正

診断用 X 線撮影に使用されているX 線管の固有沪過 を透過 X 線スペクトルを測定することから求め, JIS 規 